\title{
Cognitive and functional dementia assessment tools Review of Brazilian literature
}

\author{
Luciano Góis Vasconcelos ${ }^{1}$, Sonia Maria Dozzi Brucki², Orlando Francisco Amodeo Bueno ${ }^{3}$
}

\begin{abstract}
The diagnosis of dementia is based on cognitive and functional evaluation. One of the difficulties in ascertaining the number of people with dementia in developing countries is the population's lack of formal education. Independent effects of age, sex and education have been identified on scores for most but not all cognitive tests. Objectives: Identify the most-used cognitive and functional assessment tools in Brazil, related to dementia diagnosis and treatment outcome; and identify adaptations or normative data, when available. Methods: Data were generated from PubMed, LILACS and Portal Periodicos CAPES (thesis database) databases using the search terms 'dementia' and 'Alzheimer'. Data collection criteria were a. Articles with abstract; b. Brazilian abstracts, related to adult Brazilian population; c. Clear mention of assessment tool in the abstract text. A total of 108 abstracts were selected for the main analysis: a. to identify the instruments used b. to determine how many of the selected abstracts mentioned each tool and c. to search in the mentioned databases for respective test adaptations or normative data. Results: Some 52 different assessment tools, 41 cognitive instruments and 11 functional instruments were identified. The most cited assessment tests were the Mini Mental State Examination (64 abstracts) and Pfeffer Functional Activities Questionnaire (4 abstracts). Discussion: Many of the instruments used only have the description of the translation process into Portuguese, along with some suggestions of validation or normative data. Few of these followed the recommended procedures of validation, replication, normalization or transcultural adaptation.
\end{abstract}

Key words: neuropsychological evaluation,functional evaluation, dementia, neuropsychology.

\section{Instrumentos de avaliação cognitiva e funcional em demência}

Resumo - O diagnóstico de demência é baseado na avaliação cognitiva e funcional. Países em desenvolvimento deparam-se com uma dificuldade adicional, relacionada à baixa escolaridade formal da população. Idade, escolaridade e sexo exercem indiretamente efeitos sobre os escores da maioria dos testes cognitivos. Objetivos: Identificar os testes cognitivos e funcionais mais utilizados no Brasil, relacionados à avaliação diagnóstica e resultado de tratamento de demências; e identificar adaptações ou normatizações, quando disponíveis. Métodos: As informações foram obtidas dos bancos de dados PubMed, LILACS e Portal Periódicos CAPES (banco de teses). Digitou-se as palavras-chave 'dementia' e 'Alzheimer'. Os resumos analisados foram selecionados da pesquisa inicial através dos seguintes critérios: a. artigo com resumo; b. resumos brasileiros, relacionados à população adulta brasileira; c. clara menção do teste utilizado no texto do resumo. Os 108 resumos selecionados foram submetidos à seguinte avaliação: a. identificar os instrumentos utilizados; b. determinar o número de citações de cada teste nos diferentes resumos; c. identificar adaptações e normatizações dos testes nos bancos de dados avaliados. Resultados: foram identificados 52 diferentes instrumentos, 41 testes cognitivos e 11 funcionais. Respectivamente, os mais citados foram o Mini Exame do Estado Mental (64 resumos) e o Questionário de atividades funcionais de Pfeffer (4 resumos). Discussão: A maioria dos instrumentos utilizados tem apenas a descrição do processo de tradução, algumas sugestões de validação ou normatização. Poucos trabalhos desenvolveram todos os procedimentos recomendados para validação, replicação, normatização e adaptação trans-cultural.

Palavras-chave: demência, avaliação cognitiva, avaliação funcional, neuropsicologia.

From the Department of Psychobiology, Federal University of São Paulo, São Paulo, Brazil. ${ }^{1}$ Post-graduate student; ${ }^{2}$ Affiliated researcher; ${ }^{3}$ Adjunct Professor and Head of Department.

Dr. Luciano G. Vasconcelos - R. Embaú, 54 - 04039-060 São Paulo SP - Brazil. E-mail: goisvasconcelos@hotmail.com 


\section{Global aging trends}

The aging of the world's population is the result of two factors: declines in fertility and increases in life expectancy. Fertility rates have declined in developing countries over the past 30 years. In addition, in developed countries, the largest gain ever in life expectancy at birth occurred during the $20^{\text {th }}$ century, averaging $71 \%$ for females and $66 \%$ for males. Life expectancy at birth in developed countries now ranges from 76 to 80 years.

In 2000, the worldwide population of persons aged $\geq 65$ years was an estimated 420 million. During $2000-$ 2030 , the worldwide population aged $\geq 65$ years is projected to increase by approximately 550 million to 973 million, increasing from $6.9 \%$ to $12.0 \%$ worldwide, from $15.5 \%$ to $24.3 \%$ in Europe, from $12.6 \%$ to $20.3 \%$ in North America, from $6.0 \%$ to $12.0 \%$ in Asia, and from $5.5 \%$ to $11.6 \%$ in Latin America and the Caribbean. Between 2000-2030, the number of persons in developing countries aged $\geq 65$ years is projected to almost triple, from approximately 249 million in 2000 to an estimated 690 million in 2030, and the developing countries' share of the world's population aged $\geq 65$ years is projected to increase from $59 \%$ to $71 \%^{1}$.

\section{Brazilian aging trends}

The Brazilian elderly population ( $\geq 60$ years) increased from 3 million in 1960 to 14 million by 2002. It is projected to reach 32 million by $2020^{2}$.

Compared with developed countries, the Brazilian aging process has been faster, had deeper structural changes and has also taken place in a younger population ${ }^{3}$.

\section{Dementia and aging}

Several authors have highlighted that dementia is one of the chronic conditions that will affect a considerably increased number of elderly both in developed and developing countries.

A large number of epidemiological surveys show very similar results such as increasing rates with rising age ${ }^{4}$.

As adults live longer, the prevalence of Alzheimer's disease, which doubles every 5 years after age 65 , is also expected to increase. Approximately $10 \%$ of adults aged $\geq 65$ years and $47 \%$ of adults aged $\geq 85$ years suffer from this degenerative and debilitating disease ${ }^{5}$.

\section{Dementia around the world}

The worldwide number of persons with dementia in 2000 was estimated at about 25 million persons. Almost half of the demented persons (46\%) lived in Asia, 30\% in Europe, and $12 \%$ in North America. Fifty-two percent lived in less developed regions. About $6.1 \%$ of the popu- lation 65 years of age and older suffered from dementia (about $0.5 \%$ of the worldwide population) and $59 \%$ were female. The number of new cases of dementia in 2000 was estimated to be 4.6 million (one new case every $7 \mathrm{sec}$ onds). The forecast indicated a considerable increase in the number of demented elderly from 25 million in the year 2000 to 63 million in 2030 (41 million in less developed regions) and to 114 million in 2050 (84 million in less developed regions $)^{6,7}$.

Dementia has already been established as one of the major health challenges of this century due to the enormous burden these pathologies impose on health care systems. Dementia is a significant public health problem as it is one of the most common diseases in the elderly and a major cause of disability and mortality (Ritchie and Lovestone, 2002) ${ }^{8}$. Brazilian dementia prevalence has been estimated at 7.1\% (54.1\% Alzheimer Disease $)^{9}$.

\section{Dementia assessment tools}

The dementia diagnosis is based on cognitive and functional evaluation. Some diagnostics criteria (DSMIII, DSM-IV) highlight instrumental cognitive domain evaluations.

Use of validated assessment tools provides structure for the assessment process, helps assure consistency, and provides a mechanism for periodic re-evaluation. The assessment approaches also foster a common language for the health care team and consist of measurable parameters that can be used to monitor outcomes ${ }^{10}$.

Physicians often underestimate the extent of disability that a patient has in basic ADLs. Further, physicians' recording of the level of function in medical notes is poor. By using standardized assessment tools, the evaluation can objectively document physical, cognitive, emotional, and functional conditions. Based on the evidence, assessment tools should be chosen to aid in diagnosis and to measure outcome treatment of dementia. Older patients should be screened by standardized assessment

Table 1. Database search results.

\begin{tabular}{cc}
\hline Database & Search results \\
\hline Pubmed & 98 \\
LILACS & 456 \\
PPC $^{\dagger}$ & 284 \\
Partial result & 838 \\
Final result & 108 \\
\hline
\end{tabular}

${ }^{\star}$ After exclusion of repeated abstracts and submission to criteria collection. ${ }^{\dagger}$ Portal periódicos CAPES/Brazilian Thesis and Dissertations Database. 
Table 2. The most used cognitive assessment tools in Brazil.

\begin{tabular}{|c|c|c|}
\hline Cognitive assessment tool & $\begin{array}{l}\text { Abstracts } \\
\text { citation }^{\star}\end{array}$ & $\begin{array}{c}\text { Adaptations or } \\
\text { normative data }\end{array}$ \\
\hline 1. Mini Mental State Examination & 64 & 15 \\
\hline 2. Verbal Fluency & 9 & 16 \\
\hline 3. Trail Making & 8 & 17,18 \\
\hline 4. Digit Span & 8 & 17,18 \\
\hline 5. Blessed's Information-Memory-Concentration Test & 7 & NS $\neq$ \\
\hline 6. CAMDEX / CAMCOG & 7 & 19 \\
\hline 7. Wechsler Adult Intelligence Scale - III & 6 & 20 \\
\hline 8. Boston Naming Test & 5 & 21,22 \\
\hline 9. Neuropsi & 5 & 23 \\
\hline 10. Clock Drawing Test & 5 & 24 \\
\hline 11. Alzheimer's Disease Assessment Scale (ADAS-Cog) & 4 & 25 \\
\hline 12. Wechsler Memory Scale-Revised & 4 & 26 \\
\hline 13. Informant Questionnaire On Cognitive Decline In The Elderly (IQCODE) & 3 & NS \\
\hline 14. Consortium To Establish For Alzheimer Disease Battery (CERAD) & 3 & 27 \\
\hline 15. Clinical Interview Schedule & 3 & 28 \\
\hline 16. Wisconsin Card Sorting Test & 3 & 29 \\
\hline 17. Buschke Selective Reminding Test & 3 & 30 \\
\hline 18. Brazilian Version Of The Mattis Dementia Rating Scale (DRS) & 3 & 31,32 \\
\hline 19. Computerized Neuropsychol Test Battery (CNTB) & 2 & 33 \\
\hline 20. Stroop Test & 2 & 34 \\
\hline 21. Cognitive Abilities Screening Instrument - Short Form (CASI-S) & 2 & 35 \\
\hline 22. Protocole D'évaluation Neuropsycol Optimal Du Montreal & 2 & 36 \\
\hline 23. FAS Verbal Fluency & 2 & 37 \\
\hline 24. Word Span & 2 & 38 \\
\hline 25. Rey Auditory Verbal Learning Test & 2 & 39 \\
\hline 26. Objects Presented As Simple Drawings & 1 & 40,17 \\
\hline 27. Spatial Recognition Span & 1 & 38 \\
\hline 28. Brief Cognitive Screening Battery (BCSB) & 1 & NS \\
\hline 29. SIDAM Portuguese Version & 1 & 41 \\
\hline 30. Reduced Version Of The Face-Hand Test & 1 & 42 \\
\hline 31. Benton Visual Recognition Test & 1 & NS \\
\hline 32. Token Test & 1 & 43 \\
\hline 33. International Affective Picture System (IAPS) & 1 & 44 \\
\hline 34. Spatial Recognition Span & 1 & 39 \\
\hline 35. Porteus Mazes Test & 1 & NS \\
\hline 36. Bell Test & 1 & NS \\
\hline 37. Luria's Fist-Edge-Palm Test & 1 & 45 \\
\hline 38. California Verbal Learning Test & 1 & NS \\
\hline 39. Set-Test & 1 & NS \\
\hline 40. Short Cognitive Performance Test & 1 & 46 \\
\hline 41. Fuld Object Memory Evaluation (FOME) & 1 & NS \\
\hline
\end{tabular}

*number of abstracts citing the instrument; †reference number of adaptation or normative data suggestion; $¥$ NS, no suggestions. 
tools in order to improve diagnosis, assessment, and outcome measurement. There are many commonly used tools in dementia assessment ${ }^{11}$.

\section{Cross-cultural adaptation, validation and reliability}

One of the difficulties in ascertaining the number of people with dementia in developing countries is that many older people in these regions have little if any formal education, and often cannot read or write ${ }^{12}$.

Independent effects of age, sex, education and occupation were identified on scores for most but not all cognitive tests ${ }^{13}$. Considering that Brazil has a high number of illiterates and low educational subjects, such instruments should be adapted ${ }^{14}$.

\section{Objectives}

a. To identify the most-used cognitive and functional assessment tools in Brazil, related to dementia diagnosis and treatment outcome;

b. To identify adaptations or normative data, when available.

\section{Methods}

The literature search was performed up until September 2006. Data were generated from PubMed, LILACS and Portal Periodicos CAPES / Brazilian thesis and dissertations database (PPC) databases using the search terms 'dementia' and 'alzheimer'. For the PubMed search the term "brazil" was also included. The LILACS search only considered abstracts in English or Portuguese.
Data collection criteria: a. Articles with abstract; b. Brazilian abstracts, related to adult Brazilian population; c. Clear mention of assessment tool in the abstract text.

The search result of three databases (Table 1) was submitted to criteria above and the repeated abstracts were excluded. 108 abstracts were selected for the following analysis: a. to identify the instruments used; b. to determine how many of the selected abstracts cited each tool; and c. to search in the mentioned databases for respective test adaptations or normative data.

\section{Results}

A total of 52 different assessment tools were identified: 41 cognitive instruments and 11 functional instruments.

The most mentioned assessment tests were the Mini Mental State Examination (64 different abstracts) and the Pfeffer Functional Activities Questionnaire (4 different abstracts). All the mentioned instruments and respective suggestions of adaptations or normative data can be found in Tables 2 and 3.

Many of them only describe the translation process to Portuguese, with some superficial suggestions of validation, replication, normative data or trans-cultural adaptation. Few of them developed the recommended procedures outlined earlier.

\section{Discussion}

Many Brazilian authors have shown the influence of education on test scores: the Mini Mental State Exam-

Table 3. The most used functional assessment tools in Brazil.

\begin{tabular}{|c|c|c|}
\hline Functional assessment tools & $\begin{array}{l}\text { Abstracts } \\
\text { citation }^{\star}\end{array}$ & $\begin{array}{c}\text { Adaptations or } \\
\text { normative data } \dagger\end{array}$ \\
\hline 1. Pfeffer Functional Activities Questionnaire & 4 & NS $\ddagger$ \\
\hline 2. Activities of Daily Living (ADL) + Instrumental Activities of Daily Living (IADL) & 3 & 47 \\
\hline 3. Activities of Daily Living (ADL) & 3 & 48 \\
\hline 4. Hoehn \& Yahr Staging & 2 & 49 \\
\hline 5. Schwab \& England Scale (SES) & 2 & NS \\
\hline 6. Katz' Index of ADL & 2 & NS \\
\hline 7. Functional Assessment Staging (FAST) & 2 & NS \\
\hline 8. Bayer-Activities of Daily Living & 2 & NS \\
\hline 9. Unified Parkinson's Disease Rating Scale-Activities of Daily Living Section (UPDRS-ADL) & 1 & NS \\
\hline 10. Barthel Index & 1 & 50 \\
\hline 11. Activities of Daily Living - International Scale & 1 & NS \\
\hline
\end{tabular}

${ }^{*}$ number of abstracts citing the instrument; †reference number of adaptation or normative data suggestion; $\ddagger$ NS, no suggestions. 
ination ${ }^{15}$, Verbal Fluency Test ${ }^{16}$, Boston Naming Test ${ }^{21,22}$, ADAS- $\operatorname{Cog}^{25}, \mathrm{CERAD}^{26}$, Mattis Dementia Rating Scale ${ }^{30,31}$.

Several dementia assessment tools were identified, where few of these have followed the recommended procedures of validation, replication, normative data or trans-cultural adaptation. In the context of research use this could be acceptable, but these procedures are absolutely necessary for epidemiological surveys.

Psychometric properties of scales and trans-cultural adaptations should be developed to minimize educational influence and decrease false positive diagnosis for cognitive impairment.

Health-care professionals should be trained to recognize and evaluate quality scales and psychometric concepts such as reliability (internal consistency and testretest), validity (construct, content, face and criterion validities), and sensitivity to change (responsiveness).

Methodological problems need to be addressed, particularly development of culture- and education-fair dementia diagnostic procedures.

Consensus on assessment and outcome tools would facilitate multi-center comparative studies. One method of achieving these research goals would be through a consensus conference.

Future research should emphasize functional State, quality of life, and caregiver burden, as well as economic factors and societal perspectives.

\section{References}

1. Public Health and Aging: Trends in Aging - United States and Worldwide. Centers for Disease Control and Prevention, MMWR, 2003;52(06):101-106. Retrieved from the CDC website at: http://www.cdc.gov/MMWR/preview/ mmwrhtml/ mm5206a2.htm.

2. Lima-Costa MF, Veras R. Saúde pública e envelhecimento (Aging and public health). Cad Saúde Pública 2003;19:700701.

3. Carvalho JAM, Garcia RA. Enfoque demográfico do envelhecimento da população. Cad Saúde Pública 2003;19:725-733.

4. Wancata J, Musalek M, Alexandrowicz R, Krautgartner M. Number of dementia sufferers in Europe between the years 2000 and 2050. Eur Psychiatry 2003;18:306-313.

5. Lopes MA, Bottino CM. Prevalence of dementia in several regions of the world: analysis of epidemiologic studies from 1994 to 2000. Arq Neuropsiquiatr. 2002;60:61-69.

6. Wimo A, Winblad B, Aguero-Torres H, von Strauss E. The magnitude of dementia occurrence in the world. Alzheimer Dis Assoc Disord 2003;17:63-67.

7. Ferri CP, Prince M, Brayne C, et al. Global prevalence of dementia: a Delphi Consensus Study. Lancet 2005;366 (9503):2112-2117.
8. Berr C, Wancata J, Ritchie K. Prevalence of dementia in the elderly in Europe. Eur Neuropsychopharmacology 2005;15: 463-471.

9. Herrera Jr E, Caramelli P, Nitrini R. Population epidemiologic study of dementia in Catanduva city: state of Sao Paulo, Brazil Rev Psiquiatr Clin 1998;25:70-3.

10. Ensberg M, Gerstenlauer C. Incremental geriatric assessment. Prim Care 2005;32:619-643.

11. Wells JL, Seabrook JA, Stolee P, Borrie MJ, Knoefel F. State of the art in geriatric rehabilitation part II: Clinical challenges. Arch Phys Med Rehabil 2003;84:890-897.

12. Prince M, Acosta D, Chiu H, Scazufca M, Varghese M. Dementia diagnosis in developing countries: a cross-cultural validation study. Lancet 2003;361(9361):909-917.

13. Stewart R, Richards M, Brayne C, Mann A. Cognitive function in UK community-dwelling African Caribbean elders: normative data for a test battery. Int J Geriatr Psychiatry 2001;16:518-527.

14. Jorge MR. Adaptação transcultural de instrumentos de pesquisa em saúde mental. Rev Psiquiatr Clin 1988;25:233239.

15. Brucki SMD, Nitrini R, Caramelli P, Bertolucci PHF, Okamoto IH. Suggestions for utilization of the mini-mental state examination in Brazil. Arq Neuropsiquiatr 2003;61: 777-781.

16. Brucki SMD, Malheiros SMF, Okamoto IH, Bertolucci PHF. Normative data for the animals category verbal fluency test in our environment. Arq. Neuropsiquiatr 1997;55:56-61.

17. Nitrini R, Lefèvre BH, Mathias SC, et al. Testes neuropsicológicos de aplicação simples para o diagnóstico das demências. Arq Neuropsiquiatr 1994;52:457- 465.

18. Charchat-Fichman H. Heterogeneidade neuropsicológica no processo de envelhecimento: transição do normal aos estágios iniciais da doença de Alzheimer. Tese, Instituto de Psicologia da Universidade de São Paulo, São Paulo; 2003.

19. Bottino CMC, Stoppe A Jr, Scalco AZ, Ferreira RCR, Hototian SR, Scalco MZ. Validade e confiabilidade da versão brasileira do CAMDEX (Abstr). Arq Neuropsiquiatr 2001; 59(Suppl.3): S20.

20. Nascimento E. Adaptation and validation of test WAIS-III for a brazilian context. Tese não-publicada, Curso de Pósgraduação em Psicologia, Universidade de Brasília.Brasília, DF; 2000.

21. Radanovic M, Mansur LL, Scaff M. Normative data for the Brazilian population in the Boston diagnostic aphasia examination: influence of schooling. Braz J Med Biol Res 2004;37:1731-1738.

22. Mansur LL, Radanovic M, Araujo Gde C, Taquemori LY, Greco LL. Boston Naming Test: performance of Brazilian population from Sao Paulo. Pro Fono 2006;18:13-20.

23. Abrisqueta-Gomes J. Avaliação neuropsicológica nas fases 
inicial e moderada da demência do tipo Alzheimer. Tese, Escola Paulista de Medicina, Universidade Federal de São Paulo, São Paulo; 1999.

24. Okamoto, IH. Cognitive aspects of Alzheimer's disease in clock test: assessment in a Brazilian sample. Tese, Escola Paulista de Medicina da Universidade Federal de São Paulo; 2001.

25. Schultz RR. Desempenho de uma população brasileira na subescala cognitiva da Escala de avaliação da doença de Alzheimer (ADAS-Cog). Braz J Med Biol Res 2001;34:1295-1302.

26. Plass AM. Adaptação para o português da escala de memória de Wechsler-revisada: fidedignidade e validade. Dissertação, Universidade Federal do Rio Grande do Sul; 1991.

27. Bertolucci PHF, Okamoto IH, Toniolo J Neto, Ramos LR, Brucki S MD. Performance of Brazilian population in neuropsychological battery of Consortium to Establish a Registry for Alzheimer's disease (CERAD). Rev Psiquiatr Clin 1998;25:80-83.

28. Mari JJ, Blay SL, Iacoponi E. Reliability of the Brazilian version of the interview for communitary studies. Bol Oficina Sanit Panam 1986;100:77-83.

29. Souza RO, Ignácio FA, Cunha FCR, Oliveira DLG, Moll J. Contributions to the neuropsychology of executive behavior: performance of normal individuals on the Tower of London and Wisconsin tests. Arq Neuropsiquiatr 2001;59: 526-531.

30. Degenszajn J. Avaliacao da memoria de longa duração, recente e tardia, na doença de Alzheimer. Dissertação, Faculdade de Medicina da Universidade de São Paulo, 1998.

31. Porto CS, Fichman HC, Caramelli P, Bahia VS, Nitrini R. Brazilian version of the Mattis dementia rating scale: diagnosis of mild dementia in Alzheimer's disease. Arq. Neuropsiquiatr 2003;61: 339-345.

32. Foss MP, Valle F de AC, Speciali JG. Influência da escolaridade na avaliação neuropsicológica de idosos: aplicação e análise dos resultados da Escala de Mattis para Avaliação de Demência (Mattis Dementia Rating Scale-MDRS). Arq Neuropsiquiatr 2005;63:119-26.

33. Charchat H, Nitrini R, Caramelli P, Sameshima K. Investigação de marcadores clínicos dos estágios iniciais da doença de Alzheimer com testes neuropsicológicos computadorizados. Psicol Reflex Crit 2001;14:305-316.

34. Silva RV. O padrão de desempenho de uma amostra da população geriátrica Brasileira em testes neuropsicológicos. Dissertação, Escola Paulista de Medicina da Universidade Federal de São Paulo, 2001.

35. Damasceno A, Delicio AM, Mazo DFC, et al. Validation of the Brazilian version of mini-test CASI-S. Arq Neuropsiquiatr 2005; 63:416-421.

36. Marques PRB, Joanette Y, Poissant A, Ska, B. Adequate neuropsychological evaluation to dementias. Arq Neuropsiquiatr 1995;53:147-152.
37. Senhorini MC, Amaro Junior E, de Mello Ayres A, de Simone A, Busatto GF. Phonemic fluency in Portuguesespeaking subjects in Brazil: ranking of letters. J Clin Exp Neuropsychol 2006;28:1191-1200.

38. Chaves ML, Ilha D, Maia AL, Motta E, Lehmen R, Oliveira LM. Diagnosing dementia and normal aging: clinical relevance of brain ratios and cognitive performance in a Brazilian sample. Braz J Med Biol Res 1999;32:1133-1143.

39. Diniz LFM, Cruz MF, Torres VM, Cosenza RM. The Rey auditory-verbal learning test: norms for a brazilian sample. Rev Bras Neurol 2000;36:79-83.

40. Takada LT, Caramelli P, Charchat-Fichman $\mathrm{H}$, et al. Comparison between two tests of delayed recall for the diagnosis of dementia. Arq Neuropsiquiatr 2006;64:35-40.

41. Ventura MM, Bottino CM. Reliability study of the brazilian version of a structured interview for the diagnosis of dementia. Rev Assoc Med Bras 2001;47:110-116.

42. Blay SL. Diagnostic tests for demencial syndromes. In: Fortes JRA Miguel Filho EC, Ramadam ZBA, Arruda PV. Psiquiatria e medicina interna: Anais do $1^{\circ}$ Congresso Brasileiro de Psiquiatria e Medicina Interna; 1988.

43. Fontanari JL. The "token test": elegance and conciseness in the evaluation of understanding the aphasic patients; validative of the reduced version of De Renzi to the Portuguese. Neurobiologia 1989;52:177-218.

44. Pôrto WG. Normatization of 702 image set from the International Affective Picture System (IAPS) in a brazilian elderly sample for emotion and attention testing. Tese, Escola Paulista de Medicina da Universidade Federal de São Paulo; 2005.

45. Nitrini R, Caramelli P, Herrera Jr E, Charchat-Fichman H, Porto CS. Performance in Luria's fist-edge-palm test according to educational level. Cogn Behav Neurol 2005;18: 211-214.

46. Flaks MK, Yassuda MS, Regina AC, et al. The Short Cognitive Performance Test (SKT): a preliminary study of its psychometric properties in Brazil. Int Psychogeriatr 2006;18:121-133.

47. Costa EC, Nakatani AYK. Elder's community capacity to develop daily life activities and daily instrumental life activities. Acta Paul Enferm 2006;19:43-48.

48. Andreotti RA, Okuma SS. Validating a test battery of activities of daily living for physically independent elderly. Rev Paul Educ Fis 1999;13:46-66.

49. Goulart F, Santos CC, Teixeira-Salmela LF, Cardos F. Analysis of functional performance in patients with Parkinson's disease. Acta fisiátrica 2004;11:12-16.

50. Guimarães RB. Brazilian versions of stroke scales and clinical assessment tools: a standardization attempt plus improvement of the quality of life. Rev Bras Neurol 2004; 40: 5-13. 